\title{
Performance and Emission Profile of Micro-Algal Biodiesel in Compression Ignition Engine
}

\author{
Eloka-Eboka A.C. ${ }^{1, a *}$ and Inambao F.L. ${ }^{2, b}$ \\ 1,2 Discipline of Mechanical Engineering, University of KwaZulu-Natal, Howard College Campus, \\ Durban 4041, South Africa

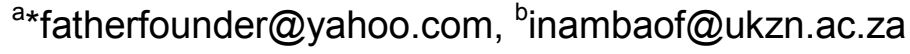

Keywords: emission profile, microalgal technology, biodiesel, compression ignition engine, open pond cultivation, photobioreactor, performance, hybridization, in situ, ex situ.

\begin{abstract}
Micro-algae are a large and diverse group of simple typically autotrophic organisms which have the potential to produce greater amounts of non-polar lipids and biomass than most terrestrial biodiesel feedstocks. Having emerged as one of the most promising sources for biodiesel production, they are gaining research interests in the current energy scenario due to their phenomenal growth potential ( $<21$ days log phase) in addition to relatively high lipids production which are also excellent source of biodiesel. In this study, engine performance and emission profile was performed using biodiesel fuels and blends from micro-algal technology in a compression ignition engine. The technology of micro-algae involved open pond cultivation and the use of photo-bioreactor model BF-115 Bioflo/celli Gen made in the US of 14 litre capacity (200 Lux light intensity) and flowrate of $2.5 \mathrm{~L} / \mathrm{min}$. The micro-algal species used were Chlorella vulgaris Scenedesmus obliquus, Senechococus spp and Duneliella spp. The biodiesel produced were blended with conventional diesel (AGO) at different proportions. The performance parameters evaluated include: engine power, torque, brake specific fuel consumption (BSFC), smoke opacity, thermal gravimetry, thermal efficiency, exhaust gas temperatures and lubricity while the varying effects of emission pollutants during combustion were also studied. Results showed that viscosity, density and lubricity have significant effects on engine output power and torque than when throttled with AGO which was used as control. Combustion efficiency and emission profile were better than the AGO due to the oxygenated nature of the micro-algal biodiesel which brought about complete combustion. A striking deduction arrived is that oxygen content of the algal biodiesel had direct influence on smoke opacity and emissions in the engine and also thermo-gravimetrically stable for other thermal applications. The engine tests (BSFC, BTE, ThE, MechE, EGT) and overall emissions $\left(\mathrm{CO}_{2}, \mathrm{CO}\right.$, VOCs, $\mathrm{HC}$, SOx, $\left.\mathrm{NOx}\right)$ were within acceptable limits and comparable with AGO. The implication of the study is that Micro-algal technology is feasible and can revolutionize development in biodiesel industry.
\end{abstract}

\section{Introduction}

There is constant rising worldwide demand for motor and power generation fuels together with environmental concerns in terms of greenhouse gases, climate change mitigation, economic growth and stability and the ongoing depletion of oil reserves. These are all major factors for the development of economically, rational, renewable energy technology platforms [1, 2]. Engineers and scientists are therefore motivated to think about various alternative sources of improved energy. The importance of developing $\mathrm{CO}_{2}$ neutral fuel sources has been highlighted by the detailed modeling of climate change effects, its global and national economic impacts and the increasing competition for fossil fuel reserves $[3,4]$. Of these, climate change appears to be the most timeconstrained driver of renewable energy technology development. This is because a reduction in $\mathrm{CO}_{2}$ emissions of $25-40 \%$ by 2020 and $80-90 \%$ by 2050 is predicted to be required to limit global temperature increases to less than the $2^{\circ} \mathrm{C}$ limit agreed at the 2009 Copenhagen Climate Change Summit [3]. In recent years, a lot of thrusts have been put on the search for the potential biomass feedstock from different sources, which can be converted to liquid as well as gas fuels for energy generation. Various feedstocks have been identified as alternative sources of energy fuels. They 
range from various kinds of bio-wastes, energy crops (edible and non-edible oil seeds); and recently various aquatic plants identified as bio-oil sources. As a result, interests have been arisen on the possibilities of using algae as a source of bio-oil and bio-gas for energy applications [5].

Algae are basically a large and diverse group of simple, typically autotrophic organisms, ranging from unicellular to multi-cellular forms. These have the potential to produce considerably greater amounts of biomass and lipids per hectare than any kind of terrestrial biomass [5]. As these can be cultivated on marginal lands, therefore do not compete with food or other crops. Algae can be cultivated photo-synthetically using sunlight for energy and $\mathrm{CO}_{2}$ as a carbon source. They may be grown in shallow lagoons or raceway ponds on marginal lands or closed ponds. Plastic tubes in ponds offer up to seven times the productivity of open ponds. A number of closed photo-bioreactors have been investigated for cost effective production of the algae [5]. The commercial viability of algae-based biofuels production shall eventually depend on economics of the technology. Regardless of whatsoever advances might come in terms of technological and biological innovations, the hard fact remains that the commercial marketplace shall have an enthusiasm for funding capital intensive energy projects, by ensuring the risk-return ratio to the acceptable stratum for debt and equity financiers. Microalgae feedstocks are gaining interest in the present day energy scenario due to their fast growth potential coupled with relatively high lipid, carbohydrate and nutrient contents. All of these properties render them an excellent source of biofuels such as biodiesel, bioethanol, and bio-methane; as well as other products. A critical evaluation of available information suggests that the economic viability of the production process in terms of minimizing the operational and maintenance cost along with maximization of oil-rich microalgae production is the key factor, for successful commercialization of algae-based fuels. The engine performance test of produced biodiesel from species of microalgae was conducted in this study. In evaluating the performance of the produced biodiesel in an internal combustion engine, certain chemo-physical properties or biodiesel characterisation were evaluated. But it is beyond the scope of this present study and therefore reported in our earlier studies

Diesel engines produce mechanical power from conversion of the chemical energy contained in the fuel. Energy is released by the combustion and oxidisation of the fuel inside the engine. The fuel-air mixture prior to combustion and the products from combustion are the working fluids. The boundary work which provides the desired power output occurs directly between these working fluids and the mechanical components of the engine [6]. Since the advent of the diesel-powered engine, compression ignition engine technology has been under continuous development. However, the basic components of the engine (Figure 1) have been unchanged, with the main difference between a modern day engine and its predecessor being its combustion performance [7]. Biodiesel can be used in modern diesel engines in its pure form (B100), or blended with petroleum diesel in any ratio [8]. There is an increasing body of literature reporting on research into diesel engine performance and engine emissions when fuelled with biodiesel. The schematic in Figure 1 describes the combustion, exhaust and fuel feed/injection systems of the diesel engine. The diesel (compression-ignition) engine is an internal combustion engine in which ignition of the fuel that has been injected into the combustion chamber is initiated by the high temperature which the diesel achieves when greatly compressed. This is called adiabatic compression. It has the highest efficiency of any standard combustion engine because of very high compression ratio achievable and also inherent lean burn that allows for heat dissipation by excess air which is very much available in biodiesel than conventional AGO due to high oxygenated nature which allows for complete combustion with lower exhaust elimination [9]. The fuel injection system contains feed pumps and filters, fuels tanks to account for low pressure and temperature maintenance at levels below flash points of the fuel. Biodiesels generally possess high flash points as one of its advantages. 


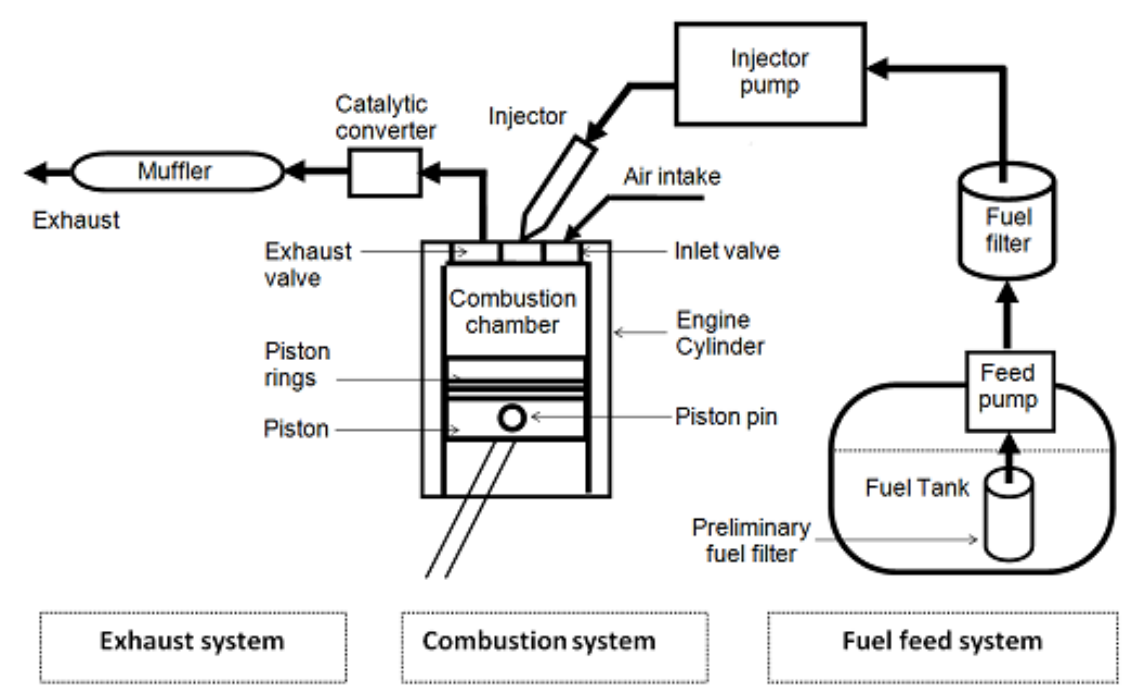

Figure 1: Schematic diagram of a typical diesel engine fuel system

\subsection{Engine performance}

Diesel engine performance parameters evaluated with biodiesel fuels in literature typically includes engine power, torque, brake specific fuel consumption (BSFC), thermal efficiency, and exhaust gas temperature (Table 1). While illustrating the effect of biodiesel on engine power and/or torque, it is commonly argued that biodiesel drops engine power and torque. This is mainly due to the lower heating value of biodiesel compared with petroleum diesel. [10] ran a four-cylinder diesel engine with waste frying oil methyl ester (WFOME), varying the engine speed from 1750 to $4400 \mathrm{rpm}$. They found on average a $4.5 \%$ and $4.3 \%$ reduction in power and torque respectively. Similar results have been reported in many other studies, with some fluctuations in the reduction percentage. Some of these studies are summarized in Table 1. Studies found that the loss of power was $7.14 \%$ for biodiesel when compared to diesel on a three-cylinder, naturally aspirated (NA) submarine diesel engine at full load, yet the loss of heating value of biodiesel was about $13.5 \%$ when compared to diesel [11-13]. Hansen et al. [12] observed that the brake torque loss was $9.1 \%$ in biodiesel at $1900 \mathrm{rpm}$ as the results of variation in heating value (13.3\%), density and viscosity. Findings from these studies confirm that the lower heating value of biodiesel is not the only factor which influences engine power and torque. Other biodiesel fuel properties including viscosity, density and lubricity have significant effects on engine output power and torque. For instance, higher viscosity of biodiesel improves air-fuel mixing by enhancing spray penetration, and thus recovery in power and torque when compared to diesel $[14,15]$. Higher viscosity can also reduce engine power by decreasing combustion efficiency due to poor fuel injection atomisation [16]. On the other hand; the higher density of biodiesel improves engine power and torque. Moreover the high lubricity in biodiesel may result in reduced friction power loss, and this will subsequently recover engine output power and torque [17]. Therefore, it is not surprising that some studies have reported increased power and torque from engines when running on biodiesel; power and torque increased with an increase in biodiesel percentage in blends while running an engine. Usta [18] also found similar results when using tobacco seed oil in a four-cylinder turbo-charged diesel engine.

Furthermore, negligible variation in engine power and torque between biodiesel and petroleum diesel has also been found [19]. More interesting results have been reported by Haşimoğin et al. [20] while using waste cooking oil biodiesel in a four-cylinder turbo-charged diesel engine operating between 1100 and $2800 \mathrm{rpm}$. This study found lower engine torque and power at lower engine speeds (1100 to $1600 \mathrm{rpm}$ ) while power and torque increased at medium and high engine speeds. However, Carraretto et al. [21] has overcome the power loss of biodiesel engine by optimising biodiesel combustion through reducing the injection advance. It is therefore evident that power and torque produced by biodiesel in the CI engines do not only depend on the nature of biodiesel feedstock and fuel properties, but also on the engine type and operating conditions, such as engine speed, load, injection timing and injection pressure. Similar correlations have been found 
in the literature for other performance parameters such as brake specific fuel consumption, thermal efficiency, exhaust gas temperature and combustion characteristics [13, 16, and 22].

\subsection{Exhaust Emissions}

Combustion chemistry in internal combustion engines (ICE) is very complex and depends on fuel types and operating conditions. In the combustion chamber, hydrocarbon reactions are generally grouped into three distinct steps.

Table 1: Performance and emission of diesel engines with biodiesel

\begin{tabular}{|c|c|c|c|c|c|c|c|c|c|c|c|c|}
\hline \multirow[t]{2}{*}{ Fuel Type } & \multirow[t]{2}{*}{ Engine } & \multirow{2}{*}{$\begin{array}{l}\text { Test } \\
\text { condition }\end{array}$} & \multicolumn{10}{|c|}{ Increase/Decrease Vs AGO (diesel) $(\downarrow \uparrow)$} \\
\hline & & & Power & Torque & BSFC & BTE & EGT & $\mathrm{CO}$ & $\mathrm{CO}_{2}$ & NOx & PM & HC \\
\hline Soybean & IC & $\begin{array}{l}1400- \\
2000 \mathrm{rpm}\end{array}$ & $\downarrow$ & $\downarrow$ & $\uparrow$ & & & $\downarrow$ & & $\downarrow$ & & $\downarrow$ \\
\hline Cottonseed & IC & 850rpm & & & $\uparrow$ & $\downarrow$ & & $\downarrow$ & & $\uparrow$ & $\downarrow$ & \\
\hline Sunflower & IC & $\begin{array}{l}1000- \\
3000 \mathrm{rpm}\end{array}$ & $\downarrow$ & $\downarrow$ & $\uparrow$ & $\downarrow$ & $\downarrow$ & $\downarrow$ & & $\downarrow$ & & \\
\hline $\begin{array}{l}\text { Waste } \\
\text { Cooking }\end{array}$ & $4 \mathrm{C}$ & $\begin{array}{l}1750- \\
4400 \mathrm{rpm}\end{array}$ & $\downarrow$ & $\downarrow$ & $\uparrow$ & & & $\downarrow$ & $\downarrow$ & $\downarrow$ & & \\
\hline Cottonseed & $4 \mathrm{C}$ & 1500rpm & $\downarrow$ & $\downarrow$ & $\uparrow$ & $\downarrow$ & & $\downarrow$ & $\downarrow$ & $\uparrow$ & $\downarrow$ & \\
\hline Sunflower & $4 \mathrm{C}$ & $\begin{array}{l}1100- \\
2800 \mathrm{rpm}\end{array}$ & $\downarrow$ & $\downarrow$ & $\uparrow$ & $\downarrow$ & $\uparrow$ & & & & $\downarrow$ & \\
\hline Soybean & $4 \mathrm{C}$ & 1400rpm & $\downarrow$ & $\downarrow$ & $\uparrow$ & $\downarrow$ & $\downarrow$ & $\downarrow$ & & $\uparrow$ & $\downarrow$ & $\downarrow$ \\
\hline $\begin{array}{l}\text { Waste } \\
\text { cooking }\end{array}$ & $4 \mathrm{C}$ & $\begin{array}{l}800- \\
1400 \mathrm{rpm}\end{array}$ & $\downarrow$ & $\downarrow$ & $\uparrow$ & $\uparrow$ & $\downarrow$ & & $\downarrow$ & $\uparrow$ & & \\
\hline $\begin{array}{l}\text { Waste } \\
\text { cooking }\end{array}$ & IC & $\begin{array}{l}1400- \\
200 \mathrm{rpm}\end{array}$ & $\downarrow$ & $\downarrow$ & $\uparrow$ & $\downarrow$ & $\downarrow$ & & $\downarrow$ & $\uparrow$ & & \\
\hline Mahua & $4 \mathrm{C}$ & $1600 \mathrm{rpm}$ & & & $\uparrow$ & $\downarrow$ & $\uparrow$ & & $\downarrow$ & $\uparrow$ & & \\
\hline Tobacco & $4 \mathrm{C}$ & $\begin{array}{l}1500- \\
300 \mathrm{rpm}\end{array}$ & $\uparrow$ & $\uparrow$ & & $\uparrow$ & $\downarrow$ & $\downarrow$ & & $\uparrow$ & & \\
\hline Rapeseed & $4 \mathrm{C}$ & $\begin{array}{l}1200- \\
2400 \mathrm{rpm}\end{array}$ & $\uparrow$ & $\uparrow$ & & & & $\downarrow$ & & $\uparrow$ & & \\
\hline $\begin{array}{l}\text { Cotton } \\
\text { seed }\end{array}$ & IC & $\begin{array}{l}1200- \\
2500 \mathrm{rpm}\end{array}$ & $\uparrow$ & $\uparrow$ & & $\uparrow$ & $\downarrow$ & $\downarrow$ & & $\uparrow$ & & \\
\hline
\end{tabular}

Source: Jahirul et al. [23].

The first step is the breakdown of hydrocarbons; the second step is the oxidation of hydrocarbons and hydrogen; the third step is the oxidation of combustion reaction products. The exhaust gas from diesel engines contains many components including carbon dioxide $\left(\mathrm{CO}_{2}\right)$, carbon monoxide $(\mathrm{CO})$, hydrogen $\left(\mathrm{H}_{2}\right)$, oxygen $\left(\mathrm{O}_{2}\right)$, sulphur oxides $(\mathrm{SOx})$, unburned hydrocarbons $(\mathrm{HC})$, particulate matter $(\mathrm{PM})$, and nitrogen oxides (NOx). These pollutants have various potential adverse health and environmental effects. Numerous studies have been conducted to investigate the effect of biodiesel on exhaust emissions in diesel engine applications. The emission parameters investigated include carbon dioxide $\left(\mathrm{CO}_{2}\right)$, carbon monoxide $(\mathrm{CO})$, hydrocarbon $(\mathrm{HC})$, nitrogen oxides $(\mathrm{NOx})$, sulphur oxides (SOx) smoke, particulate matter (PM). Most of the studies found a sharp reduction in all exhaust emissions when biodiesel was used was compared with petroleum diesel fuel (except NOx). However, a reduction in NOx in biodiesel use has also been reported in some other literature. In general, biodiesel contains about $10 \%$ oxygen by mass, while diesel has little to no oxygen. Biodiesel fuels result in more complete combustion and thereby reduces exhaust emission, and various researchers have postulated reasons for this outcome. The percentage change in emissions varies amongst these studies. The variety of results reported can be attributed to variations in the fuel properties and chemical structure of the biodiesels used, varying feedstocks and due to the variety of engines used in tests. For example, Lin et al. [24] conducted an experiment with biodiesel from eight different feedstocks and found a significant reduction in PM emissions $(50-73 \%)$. While conducting experiments with coconut, jatropha and rapeseed oil biodiesel, Lance et al. [25] showed that rapeseed oil biodiesel tended to give amongst the highest NOx emissions. Similarly, variations in emissions from biodiesels using different feedstocks have been reported in many other recent studies [26-28]. Monyem and Gerpen [15] found that oxidized biodiesel can significantly 
reduce emissions while investigating the effect of biodiesel oxidation on diesel engine emissions. This study found that oxidized biodiesel resulted in approximately $15 \%$ less CO emissions and $21 \%$ less HC emission when compared with un-oxidized biodiesel.

\subsection{Interest in Microalgae}

The interest has always been to utilize eukaryotic algae for the renewable production of several bioenergy carriers, including starches for alcohols, lipids for diesel fuel surrogates, and $\mathrm{H}_{2}$ for fuel cells. Relative to terrestrial biofuel feedstock, algae can convert solar energy into fuels (chemical energy) at higher photosynthetic efficiencies, and can thrive in salt water systems [5]. Photosynthesis is the fundamental driving force that supports all biofuel synthetic processes, converting solar energy into biomass, carbon storage products (such as carbohydrates and lipids which is the building block of fats and oil) and/or hydrogen [29].

There are already major problems of air pollution resulting from $\mathrm{CO}_{2}$ evolution and future crisis of energy due to shortage of energy sources in the world. Greenhouse gas emissions and fossil fuels combustion are calamities that have bedevilled our environments. Energy requirements are increasing continuously, because of increases in industrialization and population. The basic sources of this energy are petroleum, natural gas, coal, hydro and nuclear. The major disadvantage of using petroleum based fuels is atmospheric pollution created by the use of petroleum diesel. Petroleum diesel combustion is a major source of greenhouse gas (GHG). Apart from these emissions, petroleum diesel is also major source of other air contaminants including NOx, SOx, CO, particulate matter and volatile organic compounds (VOCs). Biomass is one of the better sources of energy. The burning of enormous amount of fossil fuel has increased the $\mathrm{CO}_{2}$ level in the atmosphere, causing global warming. The use of microalgae as a source of biofuel production has gained enormous research interests. Microalgae are able to photosynthetically convert carbon dioxide into potential biofuel feedstocks, as well as food, feeds, and high value bio-actives [30]. Micro algal crops, unlike other oil crops, are able to grow extremely fast and can double their biomass within a period of $24 \mathrm{~h}[30,31]$. Algalogy and similar studies are presently dominating studies biodiesel at the moment. Biodiesel production and testing is an emerging area of research because of the herculean tasks involved in addition to the ingenuity of strategies to be employed in not only identifying strains with better potential but also engineering the necessary technology to be adopted. Most researchers have characterised algae biodiesel but very few or none have conducted engine performances and characterisation of the emission profile nonetheless those of Chorella vulgaris, Scenedesmus spp and other strains in this study. Chorella vulgaris and Scenedesmus spp have been identified as amongst the best strains for lipids and as biodiesel precursors. This study therefore is novel and pioneering. It paves ways for researchers to proceed further in validating the experimental characterisation to real engine application.

\section{Methodology}

\subsection{Biodiesel production from Microalgae}

Samples of Chlorella vulgaris, Scenedesmus obliquus, Senechococus spp and Duneliella spp. that have been prepared and stored as innocula in the laboratory were cultivated in an open pond of plastic tank, 850L capacity and in a photobioreactor of $14 \mathrm{~L}$. In the both methods, nutrient (broth agar) were inoculated and allowed to grow for 21 days. The accumulated biomasses on harvest were subjected to solvent extraction of its lipids. The extracted oils were converted to algal biodiesel by transesterification process according to the methods adopted by Eloka-Eboka and Inambao [32]. Simple transesterification approach adopted was: settling up for solvent recovery after oil extraction: saponification reagent (SR) (methanol: $\mathrm{H}_{2} \mathrm{O}$ at the ratio of $1: 1$, methylation reagent (MR) (3.25 of $6 \mathrm{M} \mathrm{HCl}: 2.75$ methanol) and extractive reagent (ER) (Hexane: diethyl ether at the ratio of 1:1 were deployed. As the scope of study is on the performance of the biodiesel in a CI engine, methodology is limited to the use of produced algal biodiesel to power a four stroke diesel engine TD 300 and the various parameters measured as presented in the following section (2.2). 


\subsection{Engine Performance Test/Analysis}

The engine test performance and emission analysis test was conducted at the Biofuels laboratory of the Petroleum Processing Engineering Technology of Petroleum Training Institute, Effurun, Nigeria. TD 300, a versatile engine test bed with instrumentation for comprehensive investigations into the features and operating characteristics of internal combustion engines was used for the study at the petroleum Training Institute. It enables a wide range of investigations into the characteristics of four-stroke single-cylinder petrol and diesel engines. It is for use with engines up to $10 \mathrm{~kW}$ : fourstroke diesel and four-stroke petrol engines (available separately). It is a versatile regenerative engine test set with comprehensive controls and instrumentation. The equipment is fully compatible with TecQuipment's Versatile Data Acquisition System (VDAS, available separately). Using VDAS enables accurate real-time data capture, monitoring and display, calculation and charting of all relevant parameters on a computer (PC available separately) making tests quick and reliable. The main components of the system are: a heavy fabricated floor-mounting bed, an instrument console with instrument frame, a fuel tank support frame that supports the fuel tank and optional fuel gauge. The bed is held on anti-vibration mounts. It includes a robust trunnion-mounted DC machine. An electronic load cell connected to the machine measures the driving torque of the test engine. Each engine includes a colour-coded fuel tank with self-sealing couplings. The couplings ensure the engines can be connected and disconnected quickly and efficiently with minimum loss or spillage of fuel. For convenience and safety, the fuel tank can be removed for filling or for storage. The control console has an electrical cabinet which houses a four-quadrant drive to start and load the engine. The motor can also be used to drive the engine while the fuel and ignition are off, so that frictional losses can be established. The control console includes an air-box and orifice plate to measure air flow. The instrumentation and display units are mounted on a sturdy frame, which is part of the control console. The control console also includes a convenient work top for use as a writing desk, or for positioning other equipment such as a computer (computer not included). The control console and test bed are separate in order to avoid vibration being transmitted from the engine to the measuring devices. In addition, it allows the instrumentation to be thermally and acoustically screened from the test bed, using suitable shielding or a wall. The engines (available separately) include an exhaust thermocouple, dynamometer coupling, colour-coded fuel tank, hoses and fittings. They also have modified cylinder heads and cranks for connection to TecQuipment's Engine Cycle Analyser (ECA100 available separately). An Exhaust Gas Calorimeter (TD300a) is also available to enable students to measure energy lost through exhaust gases and to determine the energy balance of the engine.

In the performance experiment, the following were tested, analyzed and recorded: torque, exhaust temperature, low and high speeds, specific fuel consumption, engine flue gas emissions, $\mathrm{O}_{2}, \mathrm{CO}_{2}$, VOCs and NOx; smoke opacity using smoke meter and vibration. Having powered the diesel engine for 30 minutes of continuous run using the AGO (conventional diesel) to stabilize it, the engine was put to a hold, drained off of the AGO and ready for testing. Samples of biodiesel and blends, experimental AGO were measured out using measuring cylinder. 1000mls of each sample were poured into sample bottles as adopted by Eloka-Eboka and Ibrahim [33]. They were intermittently poured into the storage tank of the diesel engine which was modified to suit the purpose of the test. A standard $1000 \mathrm{ml}$ container was constructed for use as fuel tank and was directly connected to the injector combustion chamber so that precise data will be collected without difficulty and ran for 40 minutes for each sample. A total of 15 samples and AGO were ran and tested for the parameters already established. All the biodiesel and samples were able to power the engine creditably well without any aorta of difficulty. The speeds (rpm) were measured for each sample at different temperatures and time; using the rated power of the engine and the powertorque-speed relationship, the torque at different speeds were determined $[34,35]$.

The relationship is given as $P=2 \pi r p m$

Where, $\mathrm{P}=$ rated power; $\pi=3.142 ; \mathrm{rpm}=$ number of revolutions in $\mathrm{rpm} ; \mathrm{T}=$ torque. 
At the start of each test the test engine was operated with base fuel-diesel for about 30 minutes to attain a normal working temperature condition after that base line data were generated and the corresponding results were obtained. At every operation the engine speed was checked and maintained constant. All the measurements were repeated thrice, and the arithmetic mean of these three readings was employed for calculation and analysis. The different performance and emission parameters analyzed in the present investigation were brake thermal efficiency (BTE), brakespecific fuel consumption (BSFC), exhaust gas temperature (EGT), carbon monoxide (CO), carbon dioxide, unburned hydro-carbons (HC), nitrogen oxide (NO), and smoke.

\section{Results}

Table 2: Physico-chemical Properties of Biodiesel of produced microalgal oil

\begin{tabular}{llllllll}
\hline $\begin{array}{l}\text { Microalgal } \\
\text { biodiesel }\end{array}$ & $\begin{array}{l}\text { EC } \\
(\mathbf{w t} \%)\end{array}$ & $\mathbf{C N}$ & $\begin{array}{l}\text { SV } \\
(\mathbf{M g K O H})\end{array}$ & $\begin{array}{l}\mathbf{I V} \\
\left(\mathbf{g l}_{\mathbf{2}} \mathbf{1 0 0 g}^{-\mathbf{1}}\right)\end{array}$ & $\begin{array}{l}\text { DU } \\
(\mathbf{w t} \%)\end{array}$ & $\begin{array}{l}\text { LCSF } \\
(\mathbf{w t} \%)\end{array}$ & $\begin{array}{l}\text { CFPP } \\
\left({ }^{\mathbf{0}} \mathbf{C}\right)\end{array}$ \\
\hline $\begin{array}{l}\text { Chlorella vulgaris } \\
\text { (BA1) }\end{array}$ & 99.8 & 56.7 & 225.1 & 65.4 & 74.1 & 6.7 & 4.4 \\
$\begin{array}{l}\text { Scenedesmus } \\
\text { (BA2) }\end{array}$ & 99.8 & 56.1 & 217.5 & 65.0 & 67.8 & 11.9 & 20.4 \\
$\begin{array}{l}\text { Dunelliela (BA3) } \\
\text { Synechoccocus }\end{array}$ & 99.8 & 52.2 & 220.8 & 83.6 & 98.0 & 2.6 & -8.5 \\
(BA) & 99.8 & 54.6 & 217.9 & 68.2 & 52.7 & 6.6 & 4.3 \\
\hline
\end{tabular}

EC: ester content; $\mathrm{CN}$ : cetane number; SV: saponification value; DU: degree of unsaturation; LCSF: CFPP: Cold filters clogging point.

Table 3: Gaseous emission characteristics of biodiesel

\begin{tabular}{llllllllllll}
\hline $\begin{array}{l}\text { Algae } \\
\text { Biodiesel }\end{array}$ & $\begin{array}{l}\mathbf{C O}_{\mathbf{2}} \\
\left(\boldsymbol{\mu g} / \mathbf{m}^{\mathbf{3}}\right)\end{array}$ & $\begin{array}{l}\mathbf{N O x} \\
(\mathbf{p p m})\end{array}$ & $\begin{array}{l}\mathbf{C O} \\
(\mathbf{p p m})\end{array}$ & $\begin{array}{l}\mathbf{S O x} \\
(\mathbf{p p m})\end{array}$ & $\begin{array}{l}\text { SPM } \\
\left(\boldsymbol{\mu g} / \mathbf{m}^{\mathbf{3}}\right)\end{array}$ & $\begin{array}{l}\mathbf{H C} \\
\mathbf{( \% )}\end{array}$ & $\begin{array}{l}\text { VOC } \\
(\mathbf{\%})\end{array}$ & $\begin{array}{l}\text { Toluene } \\
(\mathbf{p p m})\end{array}$ & $\begin{array}{l}\text { Benzene } \\
(\mathbf{p p m})\end{array}$ & $\begin{array}{l}\text { Ethyl } \\
\text { Benzene } \\
(\mathbf{p p m})\end{array}$ & $\begin{array}{l}\text { Xylene } \\
(\mathbf{p p m})\end{array}$ \\
\hline AGO & 22.6 & 178 & 35.8 & 200 & 224 & 171 & 114 & 11.14 & 30.96 & 30.84 & 5.79 \\
BA1 & 19.87 & 137 & 10.22 & 163 & 131 & 93 & 138 & 6.21 & 10.13 & 13.84 & 15.77 \\
BA2 & 19.88 & 136 & 10.14 & 159 & 128 & 91 & 133 & 7.84 & 10.26 & 15.09 & 15.77 \\
BA3 & 19.87 & 133 & 10.12 & 156 & 128 & 86 & 121 & 7.93 & 10.29 & 15.62 & 15.80 \\
BA4 & 20.03 & 121 & 9.65 & 153 & 128 & 79 & 110 & 7.94 & 11.12 & 20.16 & 15.83 \\
B20 & 20.14 & 105 & 8.74 & 128 & 103 & 53 & 64 & 20.13 & 33.68 & 39.36 & 21.31 \\
\hline
\end{tabular}

Table 4: Engine exhaust emissions of algal biodiesel and AGO

\begin{tabular}{lllllllllll}
\hline $\begin{array}{l}\text { Algae } \\
\text { Biodiesel }\end{array}$ & \multicolumn{2}{l}{ CO (ppm) } & \multicolumn{2}{l}{ SOx (ppm) } & \multicolumn{2}{l}{ HC (ppm) } & \multicolumn{2}{l}{ NOx (ppm) } & \multicolumn{2}{l}{ VOCs (ppm) } \\
\hline $\begin{array}{l}\text { Engine } \\
\text { Load }\end{array}$ & $50(\%)$ & $100(\%)$ & $50(\%)$ & $100(\%)$ & $50(\%)$ & $100(\%)$ & $50(\%)$ & $100(\%)$ & $50(\%)$ & $100(\%)$ \\
\hline AGO & 0.035 & 0.018 & 150 & 200 & 171 & 220 & 420 & 660 & 1.85 & 3.4 \\
BA1 & 0.018 & 0.009 & 110 & 140 & 80 & 84 & 435 & 678 & 0.50 & 0.85 \\
BA2 & 0.020 & 0.012 & 115 & 146 & 78 & 85 & 438 & 682 & 0.50 & 0.88 \\
BA3 & 0.0209 & 0.0119 & 116 & 148 & 76 & 87 & 436 & 680 & 0.51 & 0.89 \\
BA4 & 0.0208 & 0.0118 & 117 & 150 & 75 & 88 & 436 & 681 & 0.51 & 0.89 \\
\hline
\end{tabular}




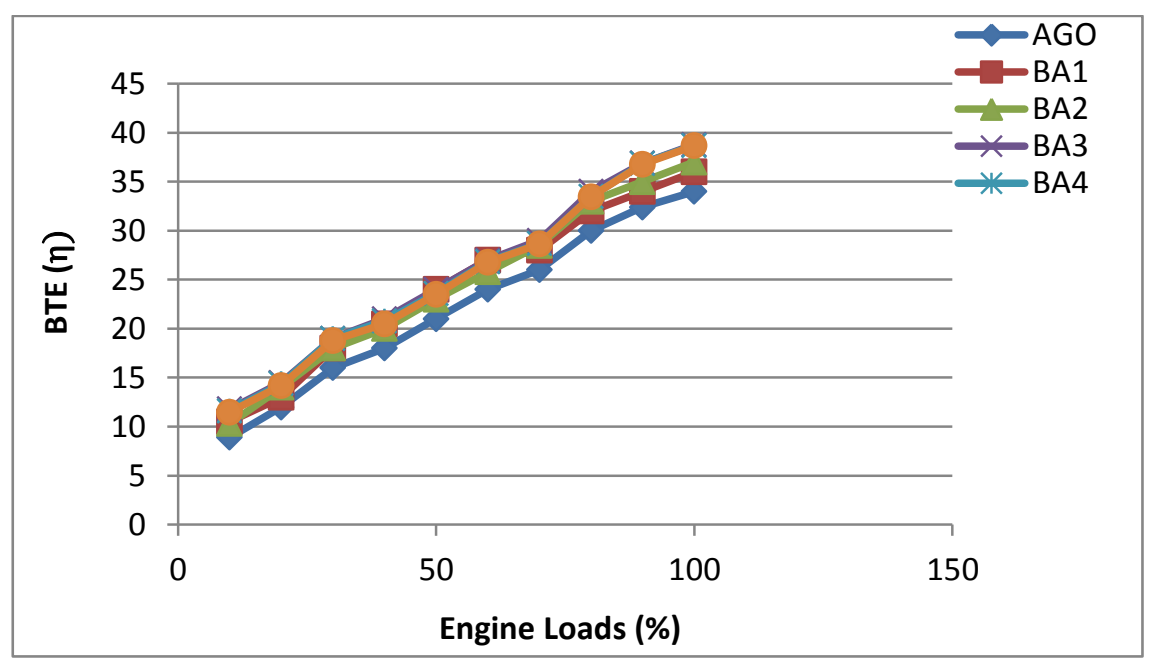

Figure 2: Effects of engine loads on the brake thermal efficiency

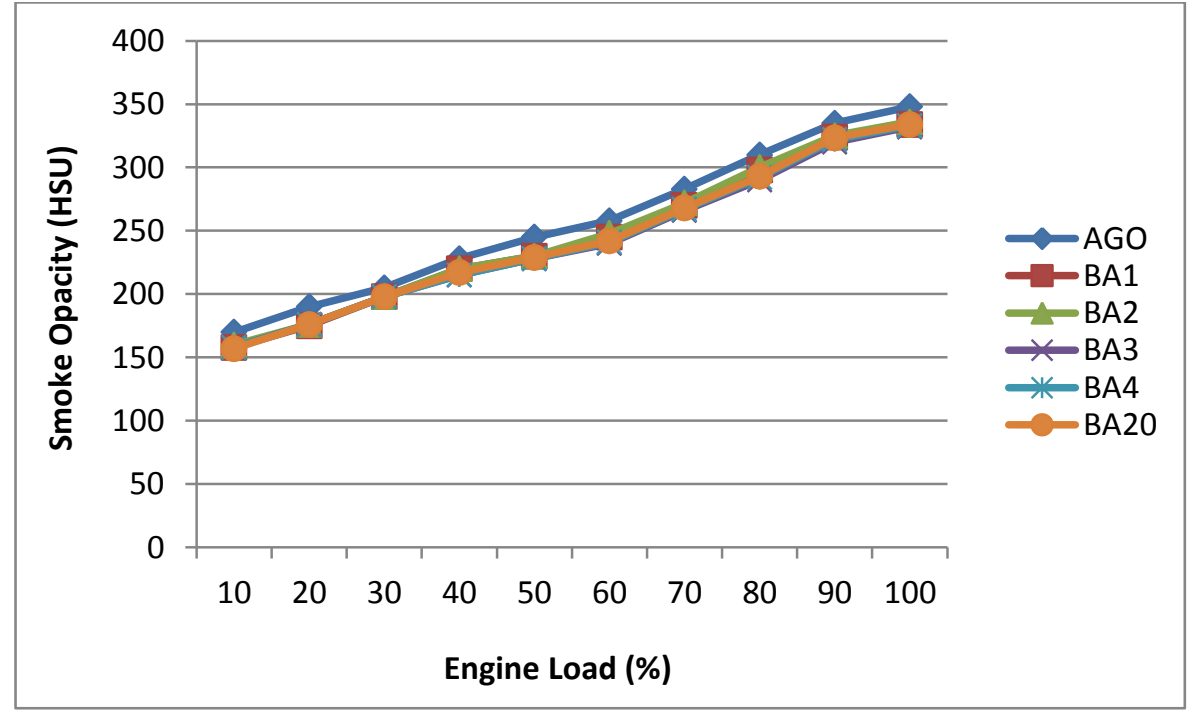

Figure 3: Effects of engine Loads on smoke density

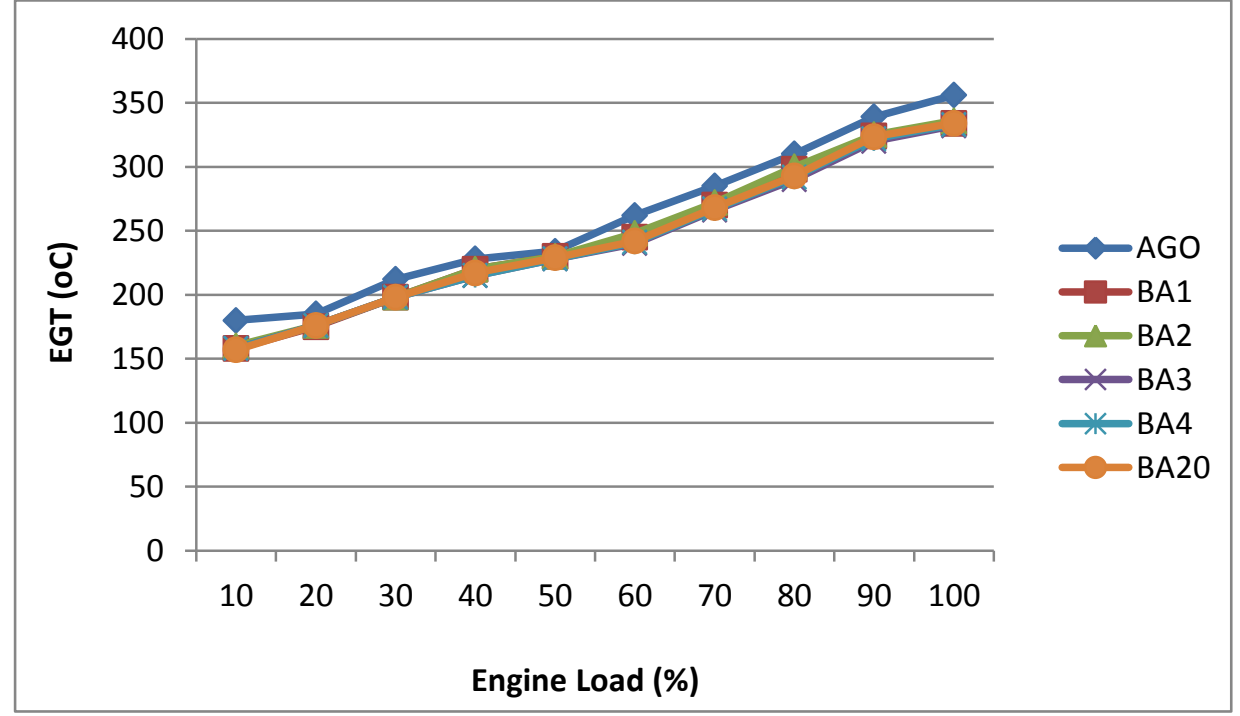

Figure 4: Effects of engine loads on exhaust gas temperature 


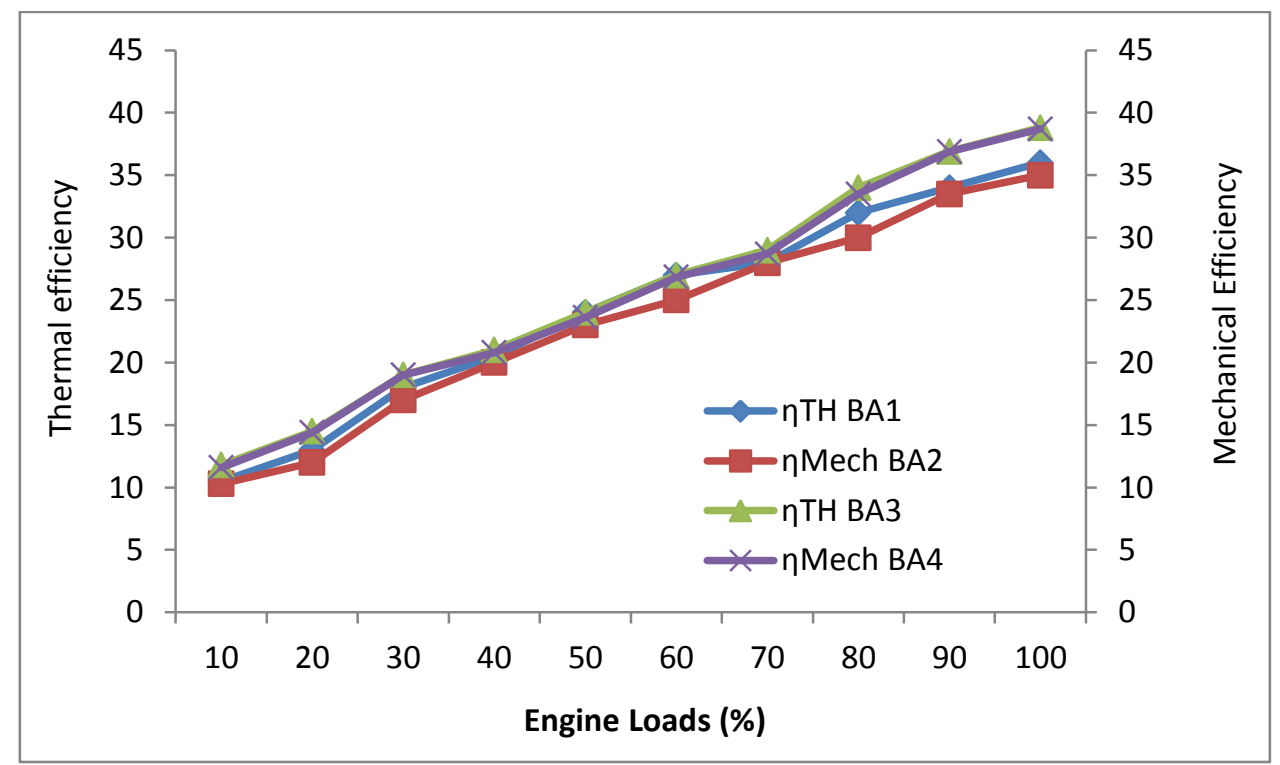

Figure 5: Effects of engine loads on thermal and mechanical efficiencies

Table 5: Engine emission and performance of AGO for comparison

\begin{tabular}{llllllll}
\hline $\begin{array}{l}\text { Speed } \\
(\mathbf{r p m})\end{array}$ & $\begin{array}{l}\text { Torque } \\
(\mathbf{N m})\end{array}$ & $\begin{array}{l}\text { Temperature } \\
\left(\mathbf{(}^{\mathbf{C}} \mathbf{C}\right)\end{array}$ & $\begin{array}{l}\text { Time } \\
(\mathbf{m i n s})\end{array}$ & $\begin{array}{l}\mathbf{C O} \\
(\mathbf{p p m})\end{array}$ & $\begin{array}{l}\mathbf{N O}_{\mathbf{2}} \\
(\mathbf{p p m})\end{array}$ & $\begin{array}{l}\text { VOCs } \\
(\mathbf{p p m})\end{array}$ & $\begin{array}{l}\mathbf{O}_{2} \\
(\mathbf{p p m})\end{array}$ \\
\hline 1000 & 6.9 & 73 & 5 & 36 & 7.8 & 0.9 & 19.2 \\
1200 & 5.8 & 74 & 10 & 40 & 9.0 & 1.1 & 19.4 \\
1400 & 4.9 & 92 & 25 & 47 & 13.7 & 1.6 & 19.6 \\
1600 & 4.3 & 101 & 20 & 47 & 15.7 & 2.0 & 19.8 \\
1800 & 3.8 & 105 & 30 & 53 & 16.5 & 2.2 & 19.9 \\
2000 & 3.4 & 107 & 40 & 58 & 18.2 & 2.4 & 20 \\
\hline
\end{tabular}

\section{Discussion}

\subsection{Engine performance test and emissions}

This section discusses general information on the engine performance tests and gaseous emission (from gas emission analyser) experimented in the compression ignition engine and some chemophysical properties as presented in Tables 2, 3, 4, 5 and Figures 3 to 5. Biodiesel usually contains higher $\mathrm{CO}_{2}$ emission than $\mathrm{AGO}$ and it is observable in in this study. It is also comparable in the works of How et al. [36] and Shirneshan et al [37]. Of particular interest is NOx which is expected to be higher in the algal biodiesel than AGO, but incidentally was not very high in this study. Most studies have reported lower NOx from some biodiesel fuels. Vashist and Ahmad [37] and Shirneshan et al. [38] reported lower Nox with biodiesel from waste frying oil and castor oil respectively. Generally, the fatty acid composition of biodiesel which contains both (saturated and polyunsaturated fatty acids) is the main index that determines its interaction/behaviour in the engine. Also the ester content (EC), Cetane number index (CN), saponification value (SV), iodine value (IV), degree of unsaturation (DU) and cold filter clogging points as indicated in Table 2. Even though polyunsaturated fatty acids produce more NOx than saturated fatty acids, but in this case a balance in composition was observed between saturation and poly-unsaturation which may be responsible for the low NOx levels. PM, HC and $\mathrm{CO}$ emission is independent of the feedstock of the biodiesel. Aromatic pollutants in biodiesel generally have lower emission compared to AGO, although emissions of benzene and several other VOCs sometimes increase as have been reported by Banapurmath et al. [28], Ozsezen et al. [27], Sahoo et al. [26], Raheman and Ghadge [22] and Ayadin and Bayindir [16]. The specific fuel consumption (SFC), specific fuel consumption rate (SFCR), brake thermal efficiency (BTE) are quite lower in AGO than in the algal biodiesel and blends by about 5\% - 31\% as the speed increases. At elevated temperatures, the performance of the 
engine improves with relatively better burning of fuel resulting in decreased $\mathrm{CO}$ in all the biodiesel even though similar characteristics was not noticed in AGO performance. Oxygen content in biodiesel had direct influence on smoke opacity. The smoke density was noticed to be reduced as the temperature increases in all the fuels samples (biodiesel, hybrids and AGO) but with higher densities in AGO. This and other trends are mainly due to the presence of internal availability of oxygen in the biodiesel and neat burning of fuel at elevated temperatures. Chemo-physical properties are indispensable indicators for the performance of biodiesel and once they fell within the ASTM limit will have significant performance and less emission which are biodegradable, nontoxic and environmentally friendly. Individual emissions and engine performance results are discussed subsequently.

\subsection{Carbon (II) oxides (CO) and carbon (IV) oxides}

Table 4 presents the emissions of carbon monoxide and carbon (IV) oxide pollutants from algal biodiesel and blends and AGO from the CI engine during performance testing at constant maximum speed of 2000rpm and at $100 \%$ load; Table 49 brings out the emissions of carbon (II) oxides across different speeds (1000, 1200, 1400, 1600, $1800 \mathrm{rpms}$ ) and engine torques (range of 3.4 to $6.9 \mathrm{Nm}$ ) at different exhaust temperatures using AGO as control while Table 4 displays the emission at 50\% and $100 \%$ loads for all the biodiesel fuels, blends and hybrids. On the effects of engine speeds on the emissions of CO. AGO recorded the highest CO through the performance tests $(22.6 \mathrm{ppm})$ and $\left(36 \mu \mathrm{g} / \mathrm{m}^{3}\right)$ measured separately at different units respectively. All the biodiesel were quite lower than the AGO. This can be accounted for by the usual complete combustion of highly oxygenated biodiesel during combustion than the AGO $[15,39]$. It is the major advantage of using biodiesel as fuels. Lower gaseous emission, environmental friendliness and biodegradability are all important characteristics. Biodiesel generally atomises during combustion due to the presence of methyl chain of the alcohol used during transesterification and so produces lesser $\mathrm{CO}_{2}$ and $\mathrm{CO}$ as compared by Agarwal [39] in his study. The effects of these emissions on engine and vice versa further explains this with a sharp disparity between emissions from biodiesel and AGO. Biodiesel fuels are also carbon neutral fuels and so its contribution to carbon emission is quite minimal.

\subsection{Nitrogen compounds (NOx)}

Tables 2 and 3 present the emissions of nitrogenous compounds (NOx) pollutants from studied biodiesel, blends and hybrids and AGO from the CI engine during performance testing at constant maximum speed of 2000rpm and at 100\% load; Table 49 brings out the emissions of carbon (II) oxides across different speeds $(1000,1200,1400,1600,1800 \mathrm{rpms})$ and engine torques (range of 3.4 to $6.9 \mathrm{Nm}$ ) at different exhaust temperatures using AGO as control while Table 50 displays the emission at 50\% and 100\% loads for all the biodiesel fuels, blends and hybrids. AGO recorded the highest NOx emission all through the performance tests $(22.6 \mathrm{ppm})$ and $(18.8 \mu \mathrm{g} / \mathrm{m} 3)$ respectively. All the biodiesel samples were quite higher than the AGO. The reason for high NOx formation at the exhaust of biodiesel than AGO is NOx formation from atmospheric nitrogen is highly dependent on the temperature, which is due to high activation energy needed for the reactions involved, and these reactions are determined by the equivalence ration, oxygen concentration and combustion temperature as well. The extra oxygen available in biodiesel causes increase in local temperature in the combustion chamber together with higher viscosity, density and bulk modulus, higher cetane index. These also affect the injection and combustion behaviour of the fuel. Most researchers have also reported increments in NOx from biodiesel [15, 40 - 41]. From the present study and other studies, the NOx is the single most critical increasing emission exhibited by biodiesel due the established reason and implication so far adduced. Table 3 presents the emissions of SOx pollutants from studied biodiesel, blends and hybrids in comparison with AGO from the CI engine during performance testing at constant maximum speed of 2000rpm and at 100\% load, AGO recorded the highest sulphur oxides emission all through the performance tests $(200 \mathrm{ppm})$ against the emissions of the biodiesel $(<<180 \mathrm{ppm})$ respectively. These are contained in the exhaust diesel system and can cause adverse health effect [41]. Sulphur compounds are acidic and can cause corrosion of tail pipes. Biodiesel however is preferable in this case because, the emissions are quite minimal. Not 
much could be discussed about the emissions of sulphur compounds as they are not very common or critical pollutant. Most literatures have rarely addressed its contribution as an exhaust gas emission.

\subsection{Hydrocarbons (HC, VOCs, PAHs)}

Table 2, 3 and 4 presents the emissions of hydrocarbons (HC) pollutants from algal biodiesel and blends with AGO from the $\mathrm{CI}$ engine during performance testing. Hydrocarbon (HC) emissions may include VOCs, PAHs and others (toluene, benzene, methyl benzene, xylene at trace levels). Diesel particulates can be characterized in terms of specific metals, elemental carbon, and organic compounds. However, it is not practically possible to speciate all organic hydrocarbons, which may number in thousands. The main source of HCs in engines is due to the incomplete combustion caused as a result of bulk quenching of flames in a fraction of the engine cycles where combustion is especially slower $[15,20]$. AGO therefore recorded the highest $\mathrm{HC}$ emission (very high) of HCs all through the performance tests (171ppm at 50\% load and $220 \mathrm{ppm}$ at $100 \% \mathrm{load})$ and $(18.8 \mu \mathrm{g} / \mathrm{m} 3)$ respectively while biodiesel samples were between 70 and $86 \mathrm{ppms}$ at $50 \%$ and $100 \%$ loads. Engine loads did not have any significant effects on the $\mathrm{HC}$ emission from biodiesel unlike those from the AGO. The VOCs from AGO which are very toxic are quite significant $(1.83 \mathrm{ppm}$ at $50 \%$ load and $3.4 \mathrm{ppm}$ at $100 \%$ load). Biodiesel and hybrids produced insignificant VOCs which are quite below toxicity levels. Soot formation is also linked to the formation of VOCs because the emission mechanism for synthesized organic compounds links to the mechanism of soot formation which is also by the presence of NOx.

\subsection{Effect of Loads on engine power, torque and efficiencies}

The effects of engine loads on brake thermal efficiencies of the algal biodiesel and AGO were evaluated in this study (Figures 2, 3, 4 and 5). Brake thermal efficiency is the ratio of brake power output to power input. It increased as the percentage of engine loads increased in all the samples (algal biodiesel with AGO) but the level of increase is lowest in AGO. Brake thermal efficiencies rise from lower to higher load level. It is because of higher power output or work done at high load level which makes for higher brake thermal efficiency. Efficiencies of 100\% Algal biodiesel were approximately higher than in AGO with $(\eta=9$ at $10 \%$ load which later peaked to 35 maximum at $100 \%$ load); BA1 and BA2 performed at efficiency of 12 at $10 \%$ load and also peaked to $\eta=40$ ). Other algal biodiesel efficiencies were between $\eta=10$ to 12 at $10 \%$ loads up to 35 at $100 \%$ load. The reason is that algal biodiesel has higher efficiency of combustion. Biodiesel from algae, therefore, may account for better combustion and therefore they have better energy conversion rate compared to diesel fuel. Variations in heating values, density and viscosity clearly influence engine torque and power. Biodiesel with lower heating values, densities and higher lubricity has significant effects on engine power and torque [10, 15]. Although, biodiesel has slightly higher density than petroleum diesel, it contains slightly less energy on a volumetric basis. This has been shown to result in a slight loss of engine power. Higher viscosity in biodiesel improves air-fuel mixing by enhancing spray penetration and homogenization in the combustion chamber and therefore greater recovery in power and torque when generally compared to fossil diesel (AGO). Oner and Altun [14] observed same in their study of biodiesel and blends in four stroke engine. In the case of this study, the response was closely comparable to AGO meaning that algal biodiesel has better biodiesel performance than other first and second generation feedstocks. It is therefore evident that power and torque generated in biodiesel engines is dependent on feedstock and fuel properties. Higher viscosity can also reduce engine power by decreasing combustion efficiency due to poor fuel injection atomisation [16]. On the other hand, the higher density of biodiesel improves engine power and torque. Moreover the high lubricity in biodiesel may result in reduced friction power loss, and this will subsequently recover engine output power and torque [10, 12 17]. Therefore, it is not surprising that some studies have reported increased power and torque from engines when running on biodiesel. 


\subsection{Effects of engine loads on smoke density}

Biodiesel from algae being highly oxygenated contains higher concentrations of oxygen which will allow faster and more complete combustion compared to fossil diesel fuel and this no doubt influences the amount or density of exhaust smoke to be released to the environment from the compression ignition engine. This is the trend observed in this study. In Figure 3, fossil diesel (AGO) produced higher smoke density (between 148 to 385 HSU (Hattridge Smoke Unit)) than all the algal biodiesel as the engine loads increased from 10 to $100 \%$. All algal biodiesel samples produced very close density of smoke amongst themselves (between 120 to $350 \mathrm{HSU}$ ) lesser than AGO. The reason for this result is that in the diesel combustion process, some of fuel droplets may never vaporize, and thus, never burn. But the fuel does not remain unchanged; the high temperatures in the combustion chamber cause it to decompose. Later, these droplets may be partly or completely burned in the turbulent flame. If they are not completely burned, they will be emitted as droplets of heavy liquid or carbon particles [39]. The conversion of fuel to particulate matter is most likely to occur when the last bit of fuel is injected in a cycle, or when the engine is being operated at high speed and high load. At higher speeds and loads, the total amount of fuel injected increases and the time available for combustion decreases resulting in higher smoke emission. Also, fuel rich region or no enough oxygen and mistimed fuel injection can substantially increase PM or smoke emission. These limitations are more obtainable in AGO than algal biodiesel because of its lean oxygen availability. The smoke emission in biodiesel fuels varies with the oxygen content of the fuel and the more oxygen content in the fuel, the less the smoke emission. In the case of algal biodiesel, they are nontoxic and biodegradable; over $90 \%$ of it will degrade within 28 days in soil or water, and this biodegradability of biodiesel in natural environment makes it an attractive fuel.

\subsection{Effects of engine load on exhaust gas temperature}

The ignition delay is a symbol of ignition ability of a fuel. The shorter ignition delay means the better ignition ability. From the experimental results, the ignition delays of methyl ester (algal biodiesel) fuels are shorter than that of the diesel fuel at every load levels in Figure 4 which clearly brought about the increase in the temperature of the exhaust gas. From this result, it can be said that the ignition abilities of biodiesel fuels are better than that of the diesel fuel. Comparing the ignition ability of biodiesel fuels and AGO, this inference is matching with the cetane number index which presented higher cetane index for all biodiesel samples thereby conferring on them higher degree of ignition quality. $\mathrm{CN}$ is one of the main indicators of the ignition quality and combustion smoothness in diesel engines. It is a dimensionless descriptor for the ignition delay time of a fuel upon injection into the combustion chamber. The higher the $\mathrm{CN}$, the shorter the ignition delay time and vice versa. It is an acceptable fact that the $\mathrm{CN}$ of biodiesel is generally higher than fossil diesel fuel due to the absence of aromatic compounds as obtained. This is in agreement with the comparison of microalgal biodiesel with other biodiesel feedstocks as reported by Igbum et al. [42], Eloka-Eboka and Onunka [43] and Monyem and Gerpen [15].

\subsection{Comparison of thermal and mechanical efficiencies}

After looking at the brake thermal efficiencies of the algal biodiesel samples and blends together with AGO and observing the effects of engine loads on them from 10 to $100 \%$, BA1 to BA4 (100\% algal biodiesel) were isolated in order to compare the effects of engine loads on thermal and mechanical efficiencies in Figure 5 since biodiesel fuels reflected higher brake thermal efficiencies than the AGO as discussed in the previous subsection. The effect was that as the engine load increased, both thermal and mechanical efficiencies increased as well almost linearly and parallel to each other. Both efficiencies are influenced by the increased combustion rate and increased heat produced together with increased torque, speed and overall power. 


\section{Conclusion}

Oxygen content in the algal biodiesel had direct influence on smoke opacity and gaseous emissions in CI engines. The smoke density reduces as temperature increases in all the fuels samples (algal biodiesel and AGO) but with higher densities in AGO. This trend is mainly due to the presence of internal availability of oxygen in the biodiesel and neat burning of fuel at elevated temperatures. Chemo-physical properties of biodiesel are the most important and indispensable factors to be considered in the production of biodiesel. Once they meet the ASTM standards, the fuels are unarguably acceptable for application in the CI engines.

Variations in heating values, density and viscosity clearly influence engine torque and power. Biodiesel with lower heating values, densities and higher lubricity has significant effects on engine power and torque. Although, biodiesel has slightly higher density than petroleum diesel, it contains slightly less energy on volumetric basis. Higher viscosity in biodiesel improves air-fuel mixing by enhancing spray penetration and homogenization in the combustion chamber and therefore greater recovery in power and torque when generally compared to fossil diesel (AGO). Higher brake specific fuel consumption of the biodiesel is due to lower net calorific value of fuels.

Algal biodiesel being highly oxygenated contains higher concentrations of oxygen which allows faster and more complete combustion compared to fossil diesel fuel and this no doubt influences the amount or density of exhaust smoke to be released to the environment from the compression ignition engine.

Algal oil is thermo-gravimetrically very stable for any thermal application. There is therefore no hindrance to conversion to biodiesel via any known process.

\section{References}

[1] Singh, S.P. and Singh, D. (2010). Biodiesel production through the use of different sources and characterization of oils and their esters as the substitute of diesel: a review. Renew Sust Energy Rev; 14:200-16.

[2] Stephens, E., Ross, I.L., Mussgnug, J.H., Wagner, L.D., Borowitzka, M.A., Posten, C., Kruse, O. and Hankamer, B. (2010). Future prospects of microalgal biofuels production systems: Trends in Plant Science Vol. 15 No. 10. 554 - 564. Elsevier Ltd.

[3] IPCC (2009). Intergovernmental Panel on climate change: Fourth Assessment report, Trends in Plant System.

[4] Stern, N. (2006). The economics of climate change, HM Treasury. www.biofuelstp.eu/algae.html Algal biofuels - Algae for production of biofuels: assessed on $8 / 3 / 11$.

[5] Beer, L.L., Boyd, E.S., Peters, J.W. and Posewitz, M.C. (2009). Engineering algae for biohydrogen and biofuels production: Current Option in Biotechnology, 20: $264-271$.

[6] Heywood, J.B. (1998). Internal Combustion Engines Fundamentals; McGrawHill: New York, NY, USA.

[7] Ferguson, C.R.; Kirkpatrick, A.T. (2001) Internal Combustion Engine, 2nd ed.; John Wiley Sons: New York, NY, USA.

[8] Lebedevas, S.; Vaicekauskas, A. (2006) Research into the application of biodiesel in the transport sector of Lithuania transport. Transport, 21, 80-87.

[9] Jaaslelainen, H. and Khar, M.K. (2013). Fuel Injection system components. DieseNet Technology Guide, EcoPoint Inc. Revision 2013.06

[10] Utlu, Z.; Koçak, M.S. (2008). The effect of biodiesel fuel obtained from waste frying oil on direct injection diesel engine performance and exhaust emissions. Renew. Energy, 33, 1936 1941.

[11] Karabektas, M. (2009). The effects of turbocharger on the performance and exhaust emissions of a diesel engine fuelled with biodiesel. Renew. Energy, 34, 989-993. 
[12] Hansen, A.C.; Gratton, M.R.; Yuan, W. (2006). Diesel engine performance and NOx emissions from oxygenated biofuels and blends with diesel fuel. Trans. Am. Soc. Agric. Biol. Eng., 49, 589-595.

[13] Murillo, S.; Miguez, J.L.; Porteiro, J.; Granada, E.; Moran, J.C. (2007). Performance and exhaust emissions in the use of biodiesel in outboard diesel engines. Fuel, 86, 1765-1771.

[14] Oner, C. and Altun, S. (2009). Biodiesel production from inedible animal tallow and an experimental investigation of its use as alternative fuel in a direct injection diesel engine. Appl. Energy, 86, 2114-2120.

[15] Monyem, A.; Gerpen, J.V. (2001). The effect of biodiesel oxidation on engine performance and emissions. Biomass Bioenergy, 20, 317-325.

[16] Aydin, H. and Bayindir, H. (2010). Performance and emission analysis of cottonseed oil methyl ester in a diesel engine. Renew. Energy, 35, 588-592.

[17] Ramadhas, A.S., Muraleedharan, C.; Jayaraj, S. (2005). Performance and emission evaluation of diesel engine fueled with methyl esters of rubber seed oil. Renew. Energy, 30, 1789-1800.

[18] Usta, N. (2005). An experimental study on performance and exhaust emissions of a diesel engine fuelled with tobacco seed oil methyl ester. Energy Convers. Manag., 4615, 23732386.

[19] Pal, A.; Verma, A.; Kachhwaha, S.S.; Maji, S. (2010). Biodiesel production through hydrodynamic cavitations and performance testing. Renew. Energy, 35, 619-624.

[20] Haşimoğlu, C.; Ciniviz, M.; Özsert, İ.; İçingür, Y.; Parlak, A.; Sahir Salman, M. (2008). Performance characteristics of a low heat rejection diesel engine operating with biodiesel. Renew. Energy, 337, 1709-1715.

[21] Carraretto, C.; Macor, A.; Mirandola, A.; Stoppato, A.; Tonon, S. (2004). Biodiesel as alternative fuel: Experimental analysis and energetic evaluations. Energy, 29, 2195-2211.

[22] Raheman, H.; Ghadge, S.V. (2007). Performance of compression ignition engine with mahua Madhuca indica biodiesel. Fuel, 8616, 2568-2573.

[23] Jahirul, M.I., R. J. Brown, W. Senadeera, I. M. O’Hara, and Z.D. Ristovski (2013). The Use of Artificial Neural Networks for Identifying Sustainable Biodiesel Feedstocks. Energies 2013, 6, 3764-3806.

[24] Lin, C.Y.; Lin, H.A.; Hung, L.B. (2006) Fuel structure and properties of biodiesel produced by the peroxidation process. Fuel, 85, 1743-1749.

[25] Lance, D.L.; Goodfellow, C.L.; Williams, J.; Bunting, W.; Sakata, I.; Yoshida, K.; Taniguchi, S., Kitano, K. (2009). The Impact of Diesel and Biodiesel Fuel Composition on a Euro V HSDI Engine with Advanced DPNR Emissions Control; SAE Technical Paper No. 2009-01190; SAE International: Washington, DC, USA.

[26] Sahoo, P.K.; Das, L.M.; Babu, M.K.G.; Arora, P.; Singh, V.P.; Kumar, N.R. (2009) Comparative evaluation of performance and emission characteristics of Jatropha, Karanja and Polanga based biodiesel as fuel in a tractor engine. Fuel, 889, 1698-1707.

[27] Ozsezen, A.N.; Canakci, M.; Turkcan, A.; Sayin, C. (2009) Performance and combustion characteristics of a DI diesel engine fuelled with waste palm oil and canola oil methyl esters. Fuel, 884,629-636.

[28] Banapurmath, N.R.; Tewari, P.G.; Hosmath, R.S. (2008). Performance and emission characteristics of a DI compression ignition engine operated on Honge, Jatropha and sesame oil methyl esters. Renew. Energy, 339, 1982-1988.

[29] Skjanes, K., Knutsen, G. kallqvist, T. and Lindblad, P. (2008). H2 production from marine and freshwater species of green algae during sulfur deprivation and considerations for bioreactor design. International Journal of Hybrid Energy (33): 511 - 521.

[30] Christi, Y. (2007). Biodiesel from microalgae. Biotechnology Advances: 25 (3): 294 - 306.

[31] Chisti, Y. (2008). Biodiesel from microalgae beats bioethanol. Trends Biotechnol. 26. 
[32] Eloka-Eboka, A.C. and Inambao, F.L. (2016). Hybridisation of feedstocks - a new approach in biodiesel development: A case of Moringa and Jatropha seed oils. Energy Sources, Part A: Recovery, Utilization, and Environmental Effects, 38:11, 1495-1502, DOI: 10.1080/15567036.2014.934413.

[33] Eloka-Eboka, A.C. and Ibrahim, J.S. (2010).Engine performance of biodiesel from African Mesquite seed Oil produced using pyrolysis published by African Journal of Physics (AJP) vol. 3. Pp. $243-256$.

[34] Eloka-Eboka, A.C. and Inambao, F.L. (2015). Engine Performance and Emission Characterization of modelled Biodiesel fuels from hybridized Moringa oleifera and Jatropha curcas seeds oils. Proceedings of the Sustainable Energy Technology Conference 2015, 25 27th August, University of Nottingham, UK.

[35] Eloka-Eboka, A.C (2015). Production, evaluation and testing of biodiesel: case studies of Moringa oleifera and selected tropical seed oils. PhD thesis, University of KwaZulu-Natal, Durban, South Africa.

[36] How, H.G., H.H. Masjuki, M.A. Kalam, Y.H. Teoh (2014). Engine performance, emission and combustion characteristics of a common-rail diesel engine fuelled with bioethanol as a fuel additive in coconut oil biodiesel blends. Energy Procedia 61: 1655 - 1659.

[37] Vashist, D. and M. Ahmad (2012). Comparative Study of Performance and Emission Characteristics of a Diesel Engine Fueled by Castor and Jatropha Methyl Ester with the Help of T Test. International Journal of Automotive Engineering Vol. 2, Number 2: 61-67.

[38] Shirneshan, Alireza (2013). $\mathrm{HC}, \mathrm{CO}, \mathrm{CO}_{2}$ and NOx Emission evaluation of a diesel engine fuelled with waste frying oil methyl ester. Procedia - Social and Behavioral Sciences 75: 292 $-297$.

[39] Agarwal, AK. (1999). Performance evaluation and tribological studies on a biodiesel-fuelled compression ignition engine. $\mathrm{PhD}$ thesis, Centre for Energy Studies, Indian Institute of Technology.

[40] Guider T.P. (2008). Characterization of Engine Performance with Biodiesel Fuels. Master of Science Thesis, Lehigh University.

[41] Xuea, Jinlin, Tony E. Grift, and Alan C. Hansen (2011). Effect of biodiesel on engine performances and emissions. Renewable and Sustainable Energy Reviews 15 (2011) 10981116.

[42] Igbum, O.G., Eloka-Eboka, A.C. and Nwadinigwe, C.A. (2012).Effects of transesterification Variables on Yields and Properties of Biodiesels Produced from Four Virgin Tropical Seeds Oils by International Journal of Environment and Bio-energy, 2012, 1(2): 119-130.

[43] Eloka-Eboka, A.C. and Onunka, C. (2016). Fuel properties Comparison of species of Microalgae and Selected second-generation oil feedstocks. African Journal of Science Technology, Innovation and Development, 8:2, 221-232. DOI: http://dx.doi.org/10.1080/20421338.2015.1128041. 